\title{
Connexin domains relevant to the chemical gating of gap junction channels
}

C. Peracchia and X.G. Wang
Department of Pharmacology and Physiology, School of Medicine and Dentistry, University of Rochester, Rochester, NY 14642-8711, USA

\author{
Correspondence \\ C. Peracchia \\ Department of Pharmacology \\ and Physiology \\ School of Medicine and Dentistry \\ University of Rochester \\ 601 Elmwood Avenue \\ Rochester, NY 14642-8711 \\ USA \\ Fax: (716) 461-3259 \\ E-mail: \\ cpera@pharmacol.rochester.edu \\ Presented at the XI Annual Meeting \\ of the Federação de Sociedades de \\ Biologia Experimental, Caxambu, \\ MG, Brasil, August 21-24, 1996. \\ Research supported by the \\ National Institutes of Health \\ (No. GM20113).

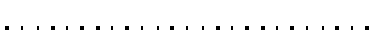

Received February 18, 1997 Accepted March 11, 1997

\begin{abstract}
Most cells exchange ions and small metabolites via gap junction channels. These channels are made of two hemichannels (connexons), each formed by the radial arrangement of six connexin $(\mathrm{Cx})$ proteins. Connexins span the bilayer four times (M1-M4) and have both aminoand carboxy-termini (NT, CT) at the cytoplasmic side of the membrane, forming two extracellular loops (E1, E2) and one inner (IL) loop. The channels are regulated by gates that close with cytosolic acidification (e.g., $\mathrm{CO}_{2}$ treatment) or increased calcium concentration, possibly via calmodulin activation. Although gap junction regulation is still unclear, connexin domains involved in gating are being defined. We have recently focused on the $\mathrm{CO}_{2}$ gating sensitivity of $\mathrm{Cx} 32$, $\mathrm{C} \times 38$ and various mutants and chimeras expressed in Xenopus oocytes and studied by double voltage clamp. $\mathrm{Cx} 32$ is weakly sensitive to $\mathrm{CO}_{2}$, whereas $\mathrm{Cx} 38$ is highly sensitive. A Cx32 chimera containing the second half of the inner loop $\left(\mathrm{IL}_{2}\right)$ of $\mathrm{Cx} 38$ was as sensitive to $\mathrm{CO}_{2}$ as $\mathrm{Cx} 38$, indicating that this domain plays an important role. Deletion of CT by $84 \%$ did not affect $\mathrm{CO}_{2}$ sensitivity, but replacement of 5 arginines $(\mathrm{R})$ with asparagines $(\mathrm{N})$ at the beginning of $\mathrm{CT}\left(\mathrm{C}_{1}\right)$ greatly enhanced the $\mathrm{CO}_{2}$ sensitivity of $\mathrm{Cx} 32$. This suggests that whereas most of CT is irrelevant, positive charges of $\mathrm{C}_{1}$ maintain the $\mathrm{CO}_{2}$ sensitivity of $\mathrm{Cx} 32$ low. As a hypothesis we have proposed a model that involves charge interaction between negative residues of the beginning of $\mathrm{IL}\left(\mathrm{IL}_{1}\right)$ and positive residues of either $\mathrm{C}_{1}$ or $\mathrm{IL}_{2}$. Open and closed channels would result from $\mathrm{IL}_{1}-\mathrm{C}_{1}$ and $\mathrm{IL}_{1}-\mathrm{IL}_{2}$ interactions, respectively.
\end{abstract}

\section{Introduction}

In most tissues, cells in contact with each other exchange charged and neutral cytosolic molecules lower than $1 \mathrm{kDa}$ in molecular mass. This exchange involves ions as well as small metabolites such as amino acids, nucleotides, second messengers and high-energy compounds, and enables electrical and metabolic signals to spread widely among cell populations (reviewed in Ref. 1). This form
Key words

- Cell-cell interaction

- Cell junctions

- Gap junctions

- Calcium

- Calmodulin

- Membrane channels 
zures (8), spreading depression (9), Chagas' disease (10), among others.

Cell coupling is mediated by channels clustered at cell-cell contact domains known as gap junctions. Each channel is formed by the extracellular interaction of two hemichannels (connexons), and creates a hydrophilic pathway that spans the two apposed plasma membranes and a narrow extracellular space (gap). In turn, each connexon is an oligomer formed by the radial arrangement of six identical proteins (connexins) that span the membrane thickness and insulate the hydrophilic pore from the lipid bilayer and the extracellular medium (reviewed in Ref. 11).

In recent years, structural studies have generated a portrait of gap junction architecture, channel framework and connexin topology. Studies on dye diffusion and metabolite exchange have defined the nature, size limit and charge characteristics of channel permeants, and the extent of metabolic cooperation among cells. Biochemistry and

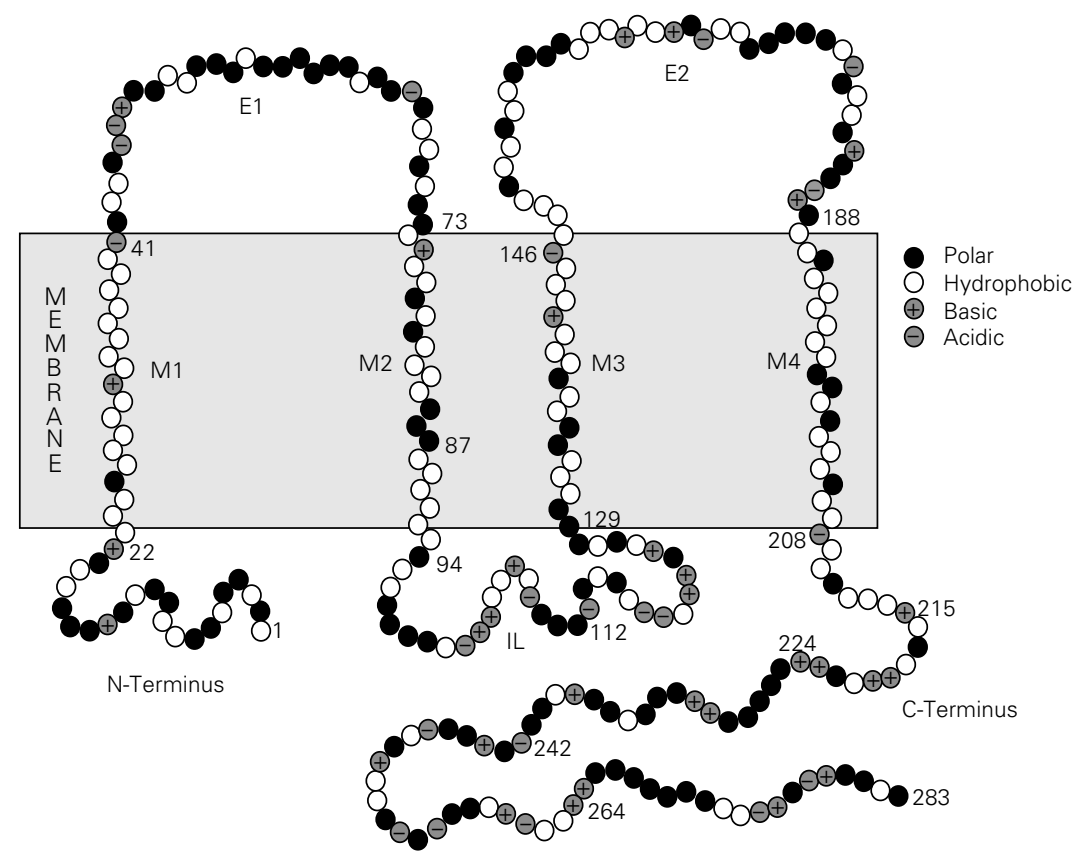

Figure 1 - Model of connexin (Cx32) topology. The molecule is believed to span the bilayer four times (M1-M4) and to have both N-and C-termini (NT, CT) at the cytoplasmic side of the membrane, forming two extracellular loops (E1, E2) and one inner loop (IL). Two connexin regions are conserved: one spans approximately the first 100 residues, comprising NT, E1, M1, M2 and the beginning of IL; the other contains M3, M4, E2 and the beginning of CT. The two remaining regions, most of $\mathrm{IL}$ and $\mathrm{CT}$, vary in sequence and length. molecular genetics have provided the means for identifying connexin sequences and for mapping secondary and tertiary structure. Electrophysiology, particularly double whole-cell patch clamp recording, the development of reliable channel expression systems, and channel reconstitution in artificial membranes have paved the way for defining single channel attributes such as conductance, gating kinetics, voltage dependence, subconductance and residual conductance states, etc., and for clarifying mechanisms of channel regulation and modulation (reviewed in Ref. 12). Nonetheless, crucial aspects of channel structure and regulation are still hypothetical.

In the absence of high resolution crystallographic information, the three-dimensional structure of connexins can only be guessed, and still unclear are the parameters that determine connexin-connexin interaction within and across junctional membranes, the structure of the channel lining, the molecular domains and the mechanisms involved in channel regulation and gating, the functional meaning of connexin diversity and differential expression, the physiological consequences of heterotypic junction formation (junctions between cells expressing different connexins), the reason for multiple connexin expression in the same cell, etc.

During the last decade at least $16 \mathrm{mem}$ bers of the connexin family have been cloned (reviewed in Ref. 12). Sequence analyses and studies using site-specific antibodies or selective proteolysis have defined connexin topology (13-22). Connexins span the bilayer four times (M1-M4) and have both amino- and carboxy-termini (NT, CT) at the cytoplasmic side of the membrane, forming two extracellular loops (E1, E2) and one inner loop (IL) (Figure 1). Two connexin regions are conserved: one spans approximately the first 100 residues, comprising NT ( $\sim 23$ residues), E1 ( $\sim 35$ residues), both M1 and M2 ( 18 residues each), and the beginning of IL; the other contains M3 (18-20 
residues), M4 ( 20 residues), E2 (44-48 residues), and the beginning of CT. The two remaining regions, most of IL and CT, vary in sequence and length. IL ranges from less than 30 residues $(\mathrm{Cx} 31.1)$ to over 70 residues $(\mathrm{Cx} 45)$, and $\mathrm{CT}$ from 18 residues (Cx26) to 188 residues (Cx56). M3 is believed to provide the channel lining structure, as it is the most amphiphilic of the four transmembrane domains.

It is still unclear how connexins interact with each other within the membrane and across the gap. Recently, we have proposed a model that envisions a staggered (one-totwo) interaction between opposite connexins (12) (Figure 2). This model is based on the idea that each junctional membrane is unlikely to be a mirror-symmetrical image of the other, because connexins are believed to be identical rather than mirror-symmetrical images of their counterparts in a gap junction. Thus, if M3 lines the channel and both E1 and E2 interact with homologous domains across the gap, a likely model would place E1 and E2 in a radial arrangement around the channel with their axes at $\sim 30^{\circ}$ angle from each other (Figure 2). In this model, opposite connexins would not bind one-to-one but rather would be staggered with each other, such that each connexin of one membrane would interact with two connexins of the adjoined membrane. Indeed, a staggered (one-to-two) connexin interaction would provide a stronger junction than a matched (one-to-one) arrangement. There are two possible configurations of the staggered model: in one, both E1 and E2 would have the same $\mathrm{N}$-to-C sequence orientation (Figure 2), centrifugal with respect to the channel, whereas in the other, only E2 would have this orientation (12).

\section{Role of calcium and $\mathrm{pH}$ in gap junction channel gating}

Functional gap junction channels are mostly in an open state, but can close in response to certain changes in the ionic composition of the cytosol. As a result of channel closure neighboring cells uncouple from each other electrically and metabolically. Although cell uncoupling is generally believed to be just a protective all-or-nothing mechanism, recent evidence for channel permeability regulation by nearly physiological changes in $\left[\mathrm{Ca}^{2+}\right]_{\mathrm{i}}(23-28)$ indicates that a fine modulation of cell communication may play a role in normal cellular functions. For understanding how cell communication is modulated physiologically and how cell coupling regulation is linked to specific cellular activities we need to define the nature of the uncoupling agents and the molecular basis of channel gating. The latter can only be defined once we fully understand which connexin domains participate in the gating mechanism.

Over the years a large body of evidence has emphasized the role of cytosolic calcium and hydrogen ions in cell coupling regulation. Evidence for gap junction channel sensitivity to internal calcium first surfaced in the mid-sixties through studies on insect gland cells (29), following an earlier observation

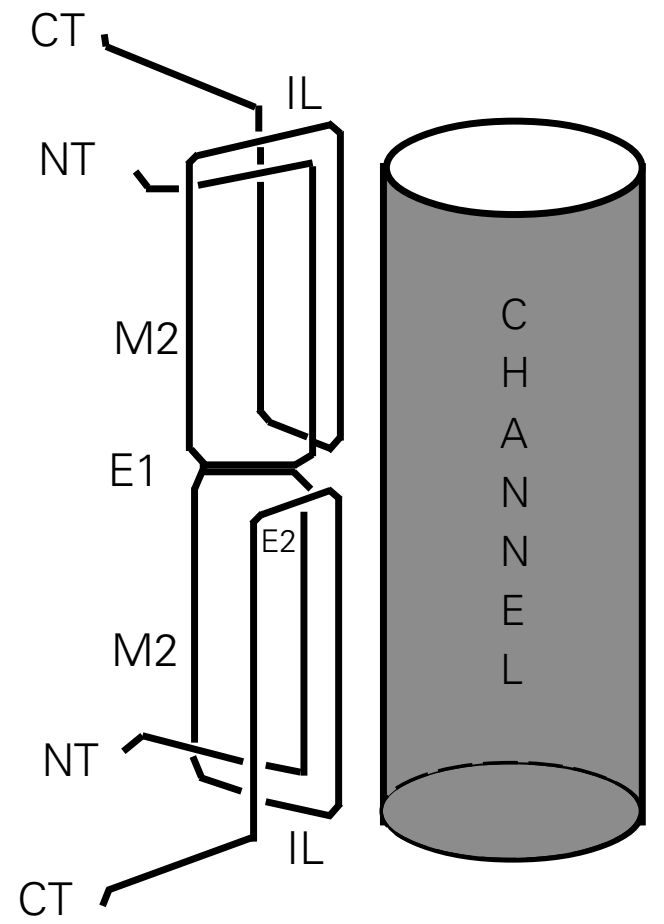

Figure 2 - Model of staggered (one-to-two) interaction between opposite connexins (12). Based on our present understanding that $\mathrm{M} 3$ lines the channel and both E1 and E2 interact with homologous domains across the gap, this model places E1 and E2 radially arranged around the channel with their axes at $\sim 30^{\circ}$ angle from each other. In this model, opposite connexins do not bind oneto-one but are staggered with each other, such that each connexin of one membrane interacts with two connexins of the adjoined membrane. There are two possible configurations of the staggered model: in one (shown here), both E's would have the same $\mathrm{N}$-to-C sequence orientation, centrifugal with respect to the channel, and in the other (see Ref. 12), only E2 would have this orientation. 
in cardiac myocytes (30). These findings were later confirmed in various cell systems (31-33). The role of $\mathrm{H}^{+}$, first proposed by Turin and Warner $(34,35)$ for amphibian embryonic cells, was later supported by Spray et al. (36) who proposed that the junctional conductance $\left(G_{j}\right)$ of these cells is a simple function of $\mathrm{pH}_{\mathrm{i}}$. However, during the last two decades a number of conflicting data on the role of calcium and $\mathrm{pH}$ have been reported $(23,24,28,37-41)$, such that it is still unclear whether $\mathrm{H}^{+}$and $\mathrm{Ca}^{2+}$ act independently from each other, and which of them regulates cell coupling under physiological circumstances.

Recently, we have tested in detail by double whole-cell patch clamp (DWCC) gap junction gating sensitivity to $\mathrm{Ca}^{2+}$ and $\mathrm{H}^{+}$in Novikoff hepatoma cell pairs internally buffered for $\mathrm{Ca}^{2+}$ with either EGTA or BAPTA, as well as the effects on $\mathrm{G}_{\mathrm{j}}$ of internal solutions buffered to various $\mathrm{pH}$ values and $\left[\mathrm{Ca}^{2+}\right]$ (24). Novikoff cells express Cx43. The effect of cytosolic acidification on $G_{j}$ varied depending on the $\mathrm{Ca}^{2+}$ buffer used. With EGTA, $\mathrm{CO}_{2}$ had a large effect on $\mathrm{G}_{\mathrm{j}}$, whereas with BAPTA it had virtually no effect. This observation suggested that $\mathrm{Ca}^{2+}$ mediates the effect of low $\mathrm{pH}_{\mathrm{i}}$ on gap junctions, as previously shown in crayfish axons (23), because the $\mathrm{Ca}^{2+}$-buffering efficiency of EGTA is severely weakened by low pH, whereas that of BAPTA is only minimally affected. The $\mathrm{Ca}^{2+}$-EGTA affinity constant drops by two orders of magnitude with a decrease in $\mathrm{pH}$ from 7 to 6 , whereas that of $\mathrm{Ca}^{2+}$-BAPTA decreases only slightly with the same $\mathrm{pH}$ drop.

For further testing this idea, we have monitored the single exponential decay of $\mathrm{G}_{\mathrm{j}}$ in cells buffered to different $\mathrm{pCa}_{\mathrm{i}}$ and $\mathrm{pH}_{\mathrm{i}}$ values. At $\mathrm{pCa}_{\mathrm{i}} 6.9$ or higher, $\mathrm{G}_{\mathrm{j}}$ decreased with a time constant $(\tau)$ of $28 \mathrm{~min}$, whereas at $\mathrm{pCa}_{\mathrm{i}} 6-6.3 \mathrm{G}_{\mathrm{j}}$ decreased with a $\tau$ of $\sim 5 \mathrm{~min}$. A $\mathrm{pCa}_{\mathrm{i}}$ of 5.5 resulted in fast uncoupling with a $\tau$ of $\sim 20 \mathrm{~s}$. The same results were obtained at $\mathrm{pH}_{\mathrm{i}} 7.2$ and at $\mathrm{pH}_{\mathrm{i}} 6.1$ (24). These data indicate that the channels of Novikoff cells are sensitive to nanomolar $\left[\mathrm{Ca}^{2+}\right]_{i}$ and are insensitive to $\mathrm{pH}_{\mathrm{i}}$, at least in the range 7.2-6.1.

Recently, we have reevaluated the relationship among $\mathrm{pH}_{\mathrm{i}}, \mathrm{pCa}_{\mathrm{i}}$ and $\mathrm{G}_{\mathrm{j}}$ in Xenopus oocyte pairs expressing Cx38 (28). Exposure to $100 \% \mathrm{CO}_{2}$ for $3 \mathrm{~min}$ caused a rapid drop of $\mathrm{G}_{\mathrm{j}}, \mathrm{pH}_{\mathrm{i}}$ and $\mathrm{pCa}_{\mathrm{i}}$ (28). The time course of $\mathrm{G}_{\mathrm{j}}$ was close to that of $\mathrm{pCa}_{\mathrm{i}}$, but contrasted sharply with that of $\mathrm{pH}_{\mathrm{i}}$ (Figure 3). This finding, also supported by the inhibitory effect of intracellularly injected BAPTA (28), further confirmed the idea that junctional permeability is more closely related to $\left[\mathrm{Ca}^{2+}\right]_{\mathrm{i}}$ than to $\left[\mathrm{H}^{+}\right]_{\mathrm{i}}$. Low $\mathrm{pH}_{\mathrm{i}}$ appears to increase $\left[\mathrm{Ca}^{2+}\right]_{\mathrm{i}}$ by releasing it from internal stores, such as endoplasmic reticulum and/ or mitochondria, rather than by increasing $\mathrm{Ca}^{2+}$ entry $(28,41)$. The lack of correspondence between $\mathrm{G}_{\mathrm{j}}$ and $\mathrm{pH}_{\mathrm{i}}$ is consistent with data obtained in other cells $(23,24,39,40)$.

In crayfish axons $(23,41)$, Novikoff cells $(24,25)$ and oocytes (28), $\mathrm{Ca}^{2+}$ appears to affect $\mathrm{G}_{\mathrm{j}}$ at nanomolar concentrations. Over the years, various $\left[\mathrm{Ca}^{2+}\right]_{\mathrm{i}}$ have been reported to induce uncoupling. Only $\left[\mathrm{Ca}^{2+}\right]_{\mathrm{i}}$ as high as $40-400 \mu \mathrm{M}$ was reported to be effective in ruptured (42) or internally perfused (43) cells, whereas low micromolar to high nanomolar concentrations were shown to induce gating in intact cells $(23,32,44-49)$. This was recently confirmed in pancreatic B-cells (26), and in Novikoff cells studied by dye coupling (27). A channel gating sensitivity to nearly physiological $\left[\mathrm{Ca}^{2+}\right]_{i}$ does not conflict with data for gap junction permeability to $\mathrm{Ca}^{2+}$ (50-52), because the gating mechanism is relatively slow at near physiological $\left[\mathrm{Ca}^{2+}\right]_{\mathrm{i}}$ (24), and because the $\left[\mathrm{Ca}^{2+}\right]_{\mathrm{i}}$ required to close all of the channels is in the high $\mathrm{nM}$ to low $\mu \mathrm{M}$ range (24), and thus above physiological values (70-200 nM).

Evidence for gap junction sensitivity to near physiological $\left[\mathrm{Ca}^{2+}\right]_{i}(23-25,28)$ indicates that modulation of cell coupling may also play a role in $\mathrm{Ca}^{2+}$-mediated phenom- 
ena involving second messengers. Indeed, we have recently found that brief exposures to arachidonic acid uncouple Novikoff hepatoma cells in a $\mathrm{Ca}^{2+}$-dependent manner, whereas long exposures affect coupling in both $\mathrm{Ca}^{2+}$-dependent and $\mathrm{Ca}^{2+}$-independent ways (25). $\mathrm{Ca}^{2+}$ participation was supported by the exquisite sensitivity of the arachidonic acid effect to $\left[\mathrm{Ca}^{2+}\right]_{\mathrm{i}}$ buffering (Figure 4). The absence of uncoupling in $\mathrm{Ca}^{2+}$-free external solutions pointed to a role of $\mathrm{Ca}^{2+}$ entry in the uncoupling process (25).

\section{Potential role of calmodulin in the uncoupling mechanism}

In the early eighties, three independent observations suggested the existence of uncoupling intermediates. Johnston and Ramón (53) reported the inability of $\mathrm{Ca}^{2+}$ and $\mathrm{H}^{+}$to uncouple internally perfused crayfish axons. Peracchia et al. $(54,55)$ suggested the participation of calmodulin (CaM) in the uncoupling mechanism, based on the ability of a CaM inhibitor (trifluoperazine) to prevent uncoupling in Xenopus embryonic cells. Hertzberg and Gilula (56) demonstrated the ability of CaM to bind to Cx32.

More recently, calmidazolium and W7, two more specific CaM blockers, inhibited uncoupling in various cells (57-61), and internally perfused crayfish axons uncoupled with $\mathrm{Ca}^{2+}$ only in the presence of CaM (62). $\mathrm{CaM}$ binding to $\mathrm{Cx} 32$ was further confirmed through gel overlay $(13,63)$ and some evidence for $\mathrm{CaM}$ association with gap junction membranes was obtained by immunoelectron microscopy (64). In pairs of cardiac myocytes in which one cell was voltage clamped and $G_{j}$ was measured after perforation of the
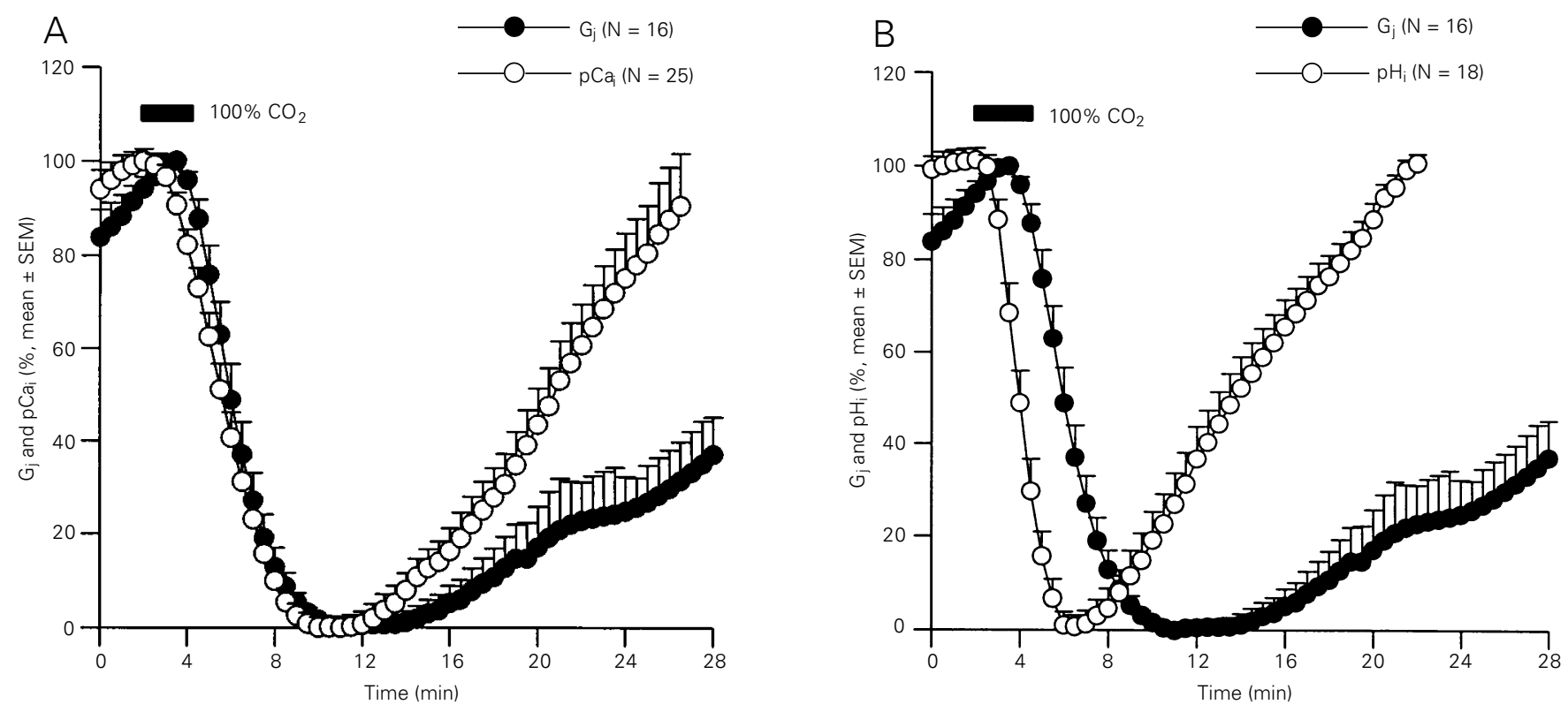

Figure 3 - Time course of changes in normalized $\mathrm{pCa}_{\mathrm{i}}(\mathrm{A}), \mathrm{pH}_{\mathrm{i}}(\mathrm{B})$ and junctional conductance $\left(\mathrm{G}_{\mathrm{j}}, \mathrm{A}\right.$ and $\left.\mathrm{B}\right)$ in Xenopus oocyte pairs exposed to $100 \% \mathrm{CO}_{2}$ for 3 min. $\mathrm{pCa}_{\mathrm{i}}$ and $\mathrm{pH}_{\mathrm{i}}$ were measured at the oocyte periphery with fura- $\mathrm{C}_{18}$ (a membrane-associated $\mathrm{Ca}^{2+}$ indicator) and $\mathrm{BCECF}$, respectively. $\mathrm{G}_{\mathrm{j}}$ was measured by double voltage clamp electrophysiology. Before $\mathrm{CO}_{2}$ exposure, the oocytes had a $\mathrm{pCa}_{i}$ of $6.66 \pm 0.17(\mathrm{mean} \pm \mathrm{SD} ; \mathrm{N}=25)$ and $\mathrm{pH}$ $\pm 0.115(\mathrm{~N}=18)$. With $\mathrm{CO}_{2}, \mathrm{pCa}$ dropped to $6.37 \pm 0.263(\mathrm{~N}=25)$ at a maximum rate of $\sim 23 \% / \mathrm{min}(\mathrm{A})$. pCa; minima were reached within $8-10$ min and $\mathrm{pCa}_{\mathrm{i}}$ recovered to normal or slightly higher than normal values within $\sim 15 \mathrm{~min}$. In contrast, $\mathrm{pH}_{\mathrm{i}}$ dropped to $6.54 \pm 0.113(\mathrm{~N}=18)$ at a maximum rate of $\sim 34 \% / \min (\mathrm{B})$. $\mathrm{pH}_{\mathrm{i}}$ minima were reached within $\sim 4 \mathrm{~min}$ and $\mathrm{pH}_{\mathrm{i}}$ recovered to normal or slightly higher than normal values within $10 \mathrm{~min}$. The time course of $\mathrm{pH}_{\mathrm{i}}$ contrasted sharply with that of $\mathrm{G}_{j}$, which dropped at a maximum rate of $\sim 25 \% / \mathrm{min}$ and was lowest 8-10 min from the beginning of the $\mathrm{CO}_{2}$ treatment ( $\mathrm{A}$ and $\mathrm{B}$ ), whereas the time course of $\mathrm{G}_{\mathrm{j}}$ was very close to that of $\mathrm{pC} \mathrm{a}_{i}$ during uncoupling. $\mathrm{pCa} \mathrm{i}_{\mathrm{i}}$ minima preceded only slightly $\mathrm{G}_{\mathrm{j}}$ minima, but $\mathrm{pCa}_{\mathrm{i}}$ recovered at a faster rate (A). From Ref. 28, with permission. 
partner cell, gap junction sensitivity to $\mathrm{Ca}^{2+}$ increased from $\mathrm{pCa}_{\mathrm{i}} 5.7$ to $\mathrm{pCa}_{\mathrm{i}} 7$ upon perfusion with $10 \mu \mathrm{M} \mathrm{CaM}$, and W7 (but not W5) prevented uncoupling (65).

To test more directly the participation of $\mathrm{CaM}$ in gating, we have studied $\mathrm{CO}_{2}$-induced uncoupling in Xenopus oocytes in which $\mathrm{CaM}$ gene expression was inhibited (28). In oocytes injected with oligonucleotides antisense to CaM mRNA, CaM mRNA was permanently degraded within $5 \mathrm{~h}$, and the oocytes gradually lost junctional sensitivity to $\mathrm{CO}_{2}$ within $72 \mathrm{~h}$. Uncoupling competence recovered by $\sim 35 \%$ following $\mathrm{CaM}$ injection. These data further confirm previous evidence for CaM participation in coupling regulation (reviewed in Ref. 12).

$\mathrm{CaM}$ could affect coupling by directly binding to connexins or by activating CaMdependent enzymes. Phosphorylation of $\mathrm{Cx} 32$ by $\mathrm{Ca}^{2+} / \mathrm{CaM}$ kinase II has been reported, but only in isolated junctions (66). Phosphatases could also play a role. There is evidence that connexins can be phosphorylated by various kinases $(66,67)$ and that connexin phosphorylation decreases with $\mathrm{Ca}^{2+}$-induced uncoupling (27). Furthermore, a difference in $\mathrm{Cx} 43$ phosphorylation has been observed between communication-competent and -deficient cell lines (67), suggesting that phosphorylation may convert impermeable hemichannels to permeable cell-cell channels.

\section{Connexin domains relevant for $\mathrm{pH} / \mathrm{Ca}^{2+}$ gating}

The molecular mechanism of $\mathrm{CO}_{2}$-induced gating is still unknown, but data on the potential involvement of certain connexin domains are accumulating. The $\mathrm{C}$-terminus domain has been suggested to play a role in determining the difference in $\mathrm{CO}_{2}$ gating sensitivity between $\mathrm{Cx} 43$ and $\mathrm{Cx} 32$, because a $\mathrm{Cx} 43$ mutant missing over $80 \%$ of it decreased in $\mathrm{pH}$ sensitivity to match that of Cx32 (40). Recently, the same group has proposed a ball-and-chain model for $\mathrm{CO}_{2}$ gating of $\mathrm{Cx} 43$ in which the carboxy-terminus (CT) end (the ball) would close the channel by binding to a receptor domain located somewhere else in Cx43. This model, similar to that proposed for $\mathrm{K}^{+}$channels $(68,69)$, is based on provocative data showing that the reduced $\mathrm{CO}_{2}$ sensitivity of a Cx43 mutant deleted at the CT end is re-
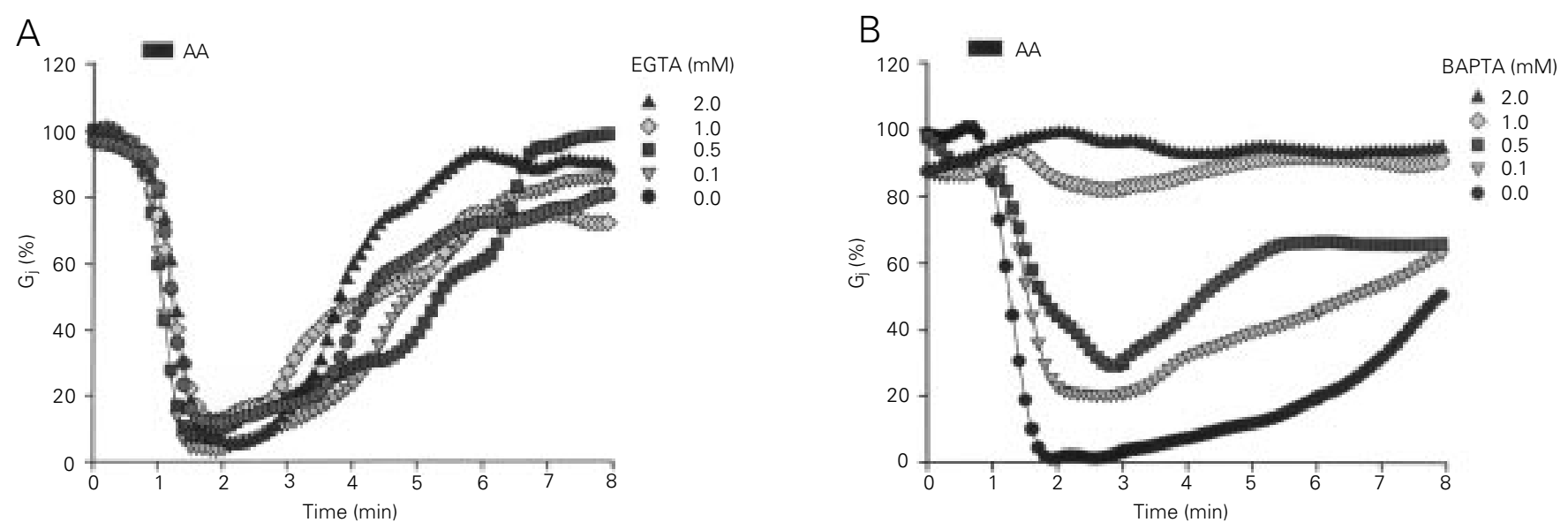

Figure 4 - Effect of arachidonic acid (AA) on electrical coupling studied in Novikoff cell pairs by double whole-cell clamp electrophysiology. The cytosol was buffered for $\mathrm{Ca}^{2+}$ through the pipette solution with either BAPTA or EGTA. The uncoupling effect of AA (20 $\left.\mu \mathrm{M}, 20 \mathrm{~s}\right)$ depends on [Ca $\left.{ }^{2+}\right]_{i}$ buffering. EGTA at concentrations as high as $2 \mathrm{mM}$ was totally ineffective in inhibiting uncoupling by AA (A). In contrast, BAPTA caused a $20 \%$ inhibition at concentrations as low as $0.1 \mathrm{mM}$ and completely eliminated the uncoupling effects of AA at 1-2 mM concentrations (B). Indeed, BAPTA is known to be a faster and more efficient intracellular $\mathrm{Ca}^{2+}$ buffer than EGTA. EGTA inhibited uncoupling by $\sim 40 \%$ and $\sim 80 \%$ at 5 and 10 mM concentrations, respectively. From Ref. 25, with permission. 
versed by coexpression of deleted $\mathrm{Cx} 43$ and the deleted CT end $(70,71)$. However, the deleted $\mathrm{Cx} 43$ was not insensitive to acidification, but just less sensitive, a finding hard to explain if the postulated gating "ball" (CT end) is missing. Nonetheless, this model may only be relevant for $\mathrm{Cx} 43$, because a Cx32 mutant in which $84 \%$ of the CT had been deleted (D219) was as sensitive to $\mathrm{CO}_{2}$ as wild-type Cx32 (72,73).

For defining connexin domain(s) of $\mathrm{Cx} 32$ participating in $\mathrm{CO}_{2}$-induced gating, we have studied the gating sensitivities to $\mathrm{CO}_{2}$ of $\mathrm{Cx} 32, \mathrm{Cx} 38$, and various chimeras and mutants of the above, expressed in Xenopus oocytes (74). Cx32 is much less sensitive to $\mathrm{CO}_{2}$ than $\mathrm{Cx} 38$. Our data show that two chimeras, $\mathrm{Cx} 32 / 38 \mathrm{I}$ (Cx32 with an inner loop, $\mathrm{IL}$, of $\mathrm{Cx} 38)$ and $\mathrm{Cx} 32 / 38 \mathrm{I}_{2}$ (Cx32 with the second half of the inner loop, $\mathrm{IL}_{2}$, of $\mathrm{Cx} 38$ ), are as sensitive to $\mathrm{CO}_{2}$ as $\mathrm{Cx} 38(74,75)$ (Figure 5). This indicates that the second half of the inner loop plays an important role in $\mathrm{pH}$ gating sensitivity.

The mechanism by which $\mathrm{IL}_{2}$ plays a role in $\mathrm{CO}_{2}$ gating sensitivity is still unclear. Spray and Burt (76) have proposed that low-pH induced uncoupling follows protonation of $\mathrm{H}$ residues. An important role in determining the $\mathrm{CO}_{2}$ sensitivity of $\mathrm{Cx} 43$ has been attributed to $\mathrm{H} 95$ (77), a residue located at the $\mathrm{N}$ terminus of IL in most connexins. Both $\mathrm{Cx} 32$ and $\mathrm{Cx} 38$ have an $\mathrm{H}$ residue at that location, but their neighboring residues are different and this could account for their difference in $\mathrm{pH}$ sensitivity. However, in view of our data on the relevance of $\mathrm{IL}_{2}$ (74), this residue may not play a key role in determining the $\mathrm{CO}_{2}$ sensitivity of $\mathrm{Cx} 32$ and $\mathrm{Cx} 38$. More relevant to channel gating could be some of the $\mathrm{H}$ residues of $\mathrm{IL}_{2}$. Recently, Hermans et al. (78) have provided preliminary evidence indicating that two $\mathrm{H}$ residues of $\mathrm{Cx} 43$ (H126 and H142) modulate in opposite ways the uncoupling effect of $\mathrm{CO}_{2}$. In $\mathrm{Cx} 32, \mathrm{IL}_{2}$ contains two $\mathrm{H}$ residues (H123 and H126). Although in preliminary experiments the re- placement of $\mathrm{H} 126$ with $\mathrm{R}$ did not affect the $\mathrm{CO}_{2}$ sensitivity of $\mathrm{Cx} 32$ (75), a more detailed evaluation of the potential role of these two residues is presently underway in our laboratory.

Since CT chimeras did not express functional channels, the potential role of CT could not be tested with chimeras, but interesting data were obtained with mutations of basic residues at its initial 18-residue segment $\left(\mathrm{C}_{1}\right)$ and with $\mathrm{CT}$ deletions. Although much of the $\mathrm{C}$-terminus of $\mathrm{Cx} 32$ seems not to play a significant role in $\mathrm{CO}_{2}$-gating sensitivity, as $84 \%$ deletion of it at residue 219 (Cx32-D219) does not affect $\mathrm{CO}_{2}$ sensitivity $(72,73)$ (Figure 6), the $\mathrm{C}_{1}$ domain (Figure 7) appears to have an inhibitory role. This is suggested by our recent data with mutants in which some or all of the positively charged residues $(\mathrm{R})$ of $\mathrm{C}_{1}$ were replaced with neutral (polar) residues $(\mathrm{N}$ or $\mathrm{T})$ (73). Progressive replacement of $\mathrm{R}$ with $\mathrm{N}$ residues resulted in

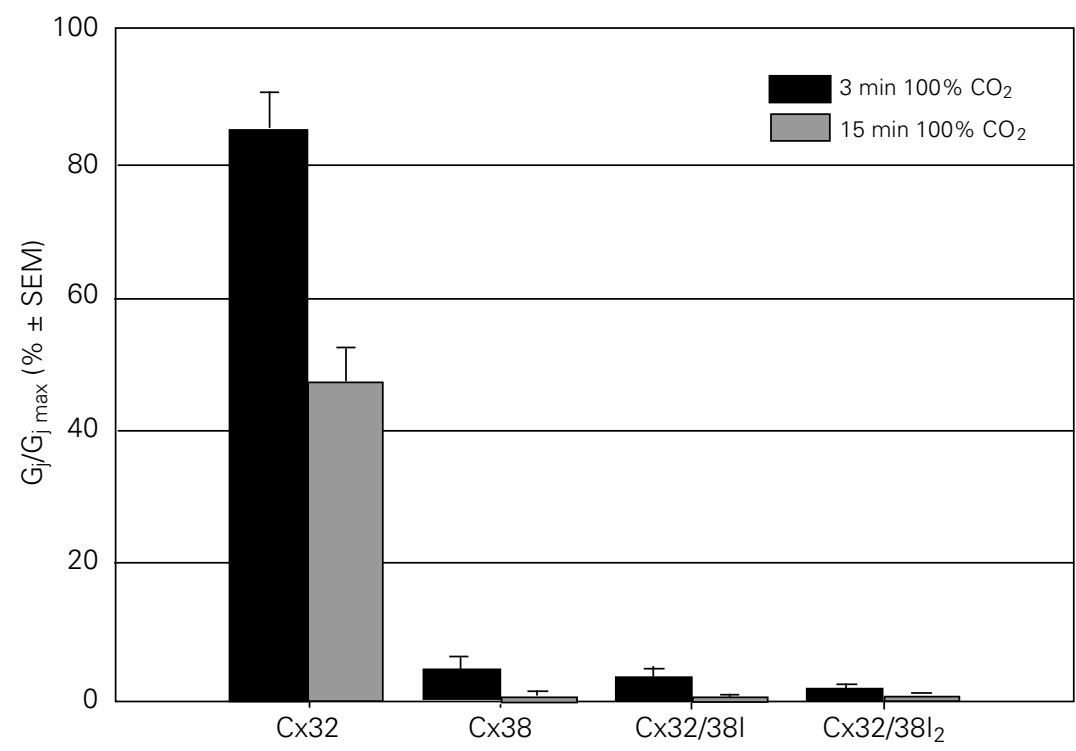

Figure 5 - Junctional sensitivity to $\mathrm{CO}_{2}$, expressed as normalized junctional conductance $\left(\mathrm{G}_{\mathrm{j}} /\right.$ $\mathrm{G}_{\mathrm{j} \text { max }} ; 100 \%=$ control, pretreatment value), in oocyte pairs expressing $\mathrm{C} \times 32, \mathrm{Cx} 38$ or $\mathrm{C} \times 32 /$ 38 chimeras $(74,75)$. With $\mathrm{C} \times 38$, a 3-min exposure to $\mathrm{CO}_{2}$ decreased $\mathrm{G}_{j}$ to nearly $0 \%$, whereas with $\mathrm{C} \times 32$, even a 15 -min $\mathrm{CO}_{2}$ treatment decreased $\mathrm{G}_{\mathrm{j}}$ by only $\sim 55 \%$. Two chimeras, $\mathrm{C} \times 32 / 38$ I (inner loop of $\mathrm{C} \times 32$ replaced by that of $\mathrm{C} \times 38$ ) and $\mathrm{C} \times 32 / 38 \mathrm{I}_{2}$ (second half of inner loop, $\mathrm{IL}_{2}$, of $\mathrm{C} \times 32$ replaced by that of $\mathrm{C} \times 38$ ), reproduced the uncoupling efficiency of $\mathrm{C} \times 38$. This indicates that $\mathrm{IL}_{2}$ plays an important role in $\mathrm{pH}$ gating sensitivity. The $\mathrm{N}$ terminal domain does not appear to be relevant because the chimera $\mathrm{C} \times 32 / 38 \mathrm{~N}$ ( $\mathrm{C} \times 32$ with NT of $\mathrm{C} \times 38$ ) behaved similarly to $\mathrm{C} \times 32$ (see Ref. 74). 
A

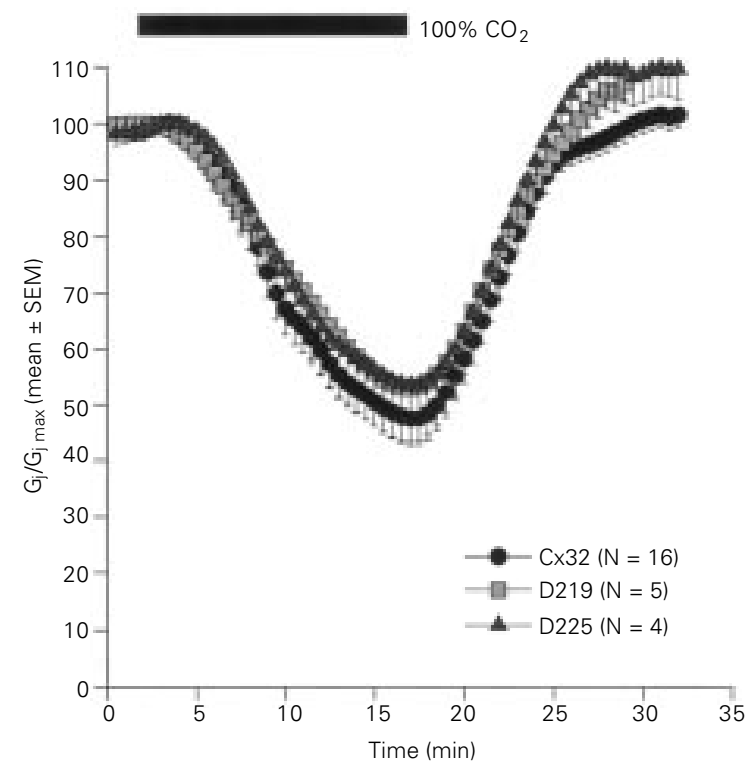

B

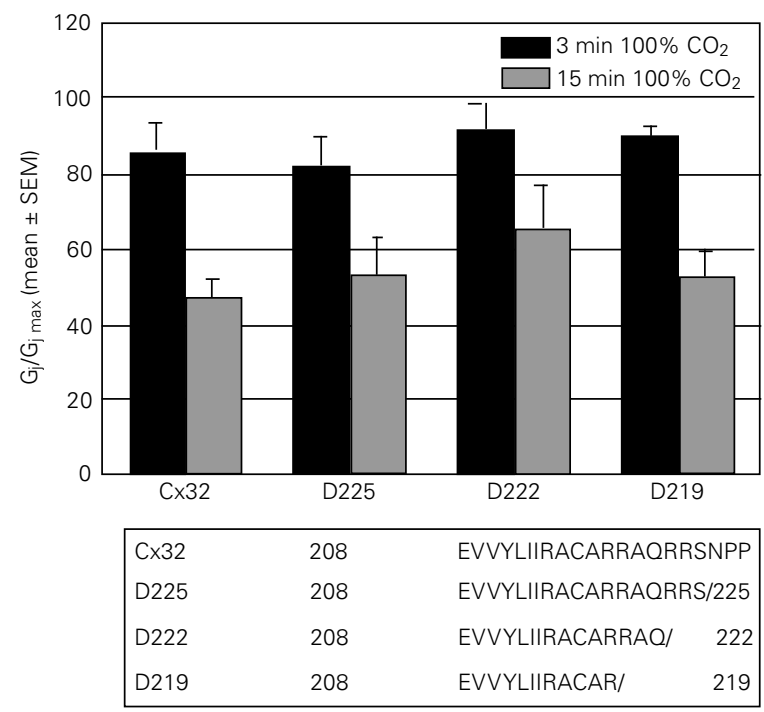

Figure 6 - Decrease in junctional conductance $\left(\mathrm{G}_{\mathrm{j}}\right)$ in Xenopus oocyte pairs, expressing wild-type $\mathrm{C} \times 32$ or $\mathrm{C} \times 32$ deleted of most of the $\mathrm{C}$-terminus, with exposure to $100 \% \mathrm{CO}_{2}$ for either $15 \mathrm{~min}(\mathrm{~A}$ and $\mathrm{B}$ ) or $3 \mathrm{~min}(\mathrm{~B})$. Note that deletion of the $\mathrm{C}$-terminus by over $80 \%$ (D225, D222, D219) did not affect $\mathrm{CO}_{2}$ sensitivity. With 3 min $\mathrm{CO}_{2}, \mathrm{G}_{\mathrm{j}}$ dropped to $82 \pm 8 \%, 91 \pm 7 \%$ and $90 \pm 3 \%$ (mean \pm SEM) with D225, D222 and D219, respectively, and with 15 min $\mathrm{CO}_{2}$, to $53.5 \pm 10 \%, 65 \pm 11 \%$ and $53 \pm 7 \%$ with D225, D222 and D219, respectively.

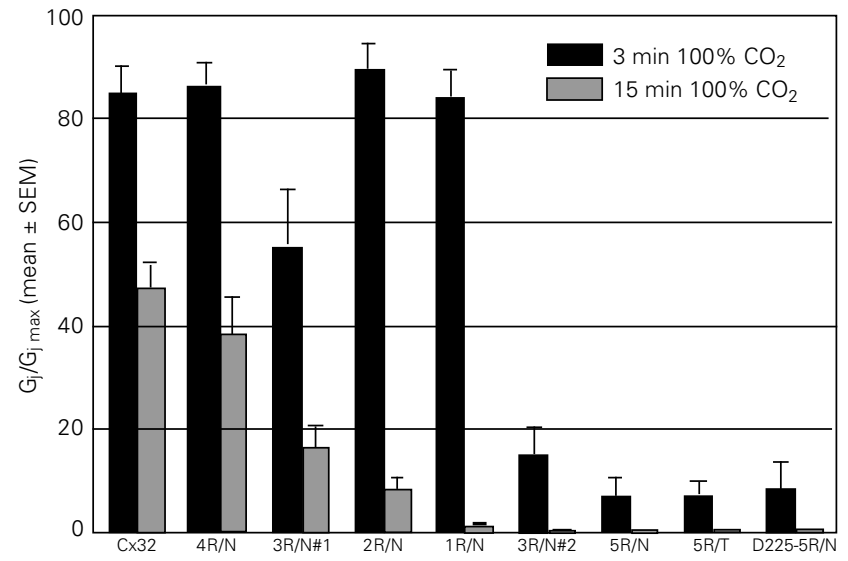

\begin{tabular}{|c|c|c|}
\hline Cx32 & 215 & RACARRAQRRSNP P \\
\hline $4 R / N$ & 215 & $\mathrm{R}---\mathrm{NN}--\mathrm{NN}----$ \\
\hline 3R/N\# 1 & 215 & $\mathrm{~N}---\mathrm{RR}--\mathrm{NN}----$ \\
\hline $2 \mathrm{R} / \mathrm{N}$ & 215 & $\mathrm{R}---\mathrm{NN}--\mathrm{RR}----$ \\
\hline $1 \mathrm{R} / \mathrm{N}$ & 215 & $\mathrm{~N}---\mathrm{RR}--\mathrm{RR}----$ \\
\hline $3 R / N \# 2$ & 215 & $\mathrm{~N}---\mathrm{NN}--\mathrm{RR}----$ \\
\hline $5 R / N$ & 215 & $\mathrm{~N}---\mathrm{NN}--\mathrm{NN}----$ \\
\hline $5 \mathrm{R} / \mathrm{T}$ & 215 & $\mathrm{~T}---\mathrm{TT}--\mathrm{TT}---$ \\
\hline D22 $5-5 R / N$ & 215 & $\mathrm{~N}---\mathrm{NN}--\mathrm{NN}-/ 225$ \\
\hline
\end{tabular}

Figure 7 - Summary of the effects of partial or total replacement of arginine $(\mathrm{R})$ residues with asparagine (N) or threonine $(T)$ residues in the initial domain $\left(C_{1}\right)$ of the $\mathrm{C}$-terminus chain, on normalized $\mathrm{G}_{\mathrm{j}}\left(\mathrm{G}_{\mathrm{j}} / \mathrm{G}_{\mathrm{imax}} ; 100 \%\right.$ $=$ control, pretreatment value), following 3 -min or $15-$ min exposure to $\mathrm{CO}_{2}$. Note that replacement of all of the $5 \mathrm{R}$ with $\mathrm{N}$ or T residues greatly increased the $\mathrm{CO}_{2}$ sensitivity of $\mathrm{C} \times 32$, whereas partial $\mathrm{R} / \mathrm{N}$ replacement resulted in intermediate $\mathrm{CO}_{2}$ sensitivities. This indicates that the $\mathrm{R}$ residues differ in their ability to inhibit the $\mathrm{CO}_{2}$ sensitivity of $\mathrm{C} \times 32$. R215 appears to have greater inhibitory power than R219-220. In contrast, R223-224 seems to partly counteract the inhibitory activity of both R215 and R219-220, because $2 R / N$ and $1 \mathrm{R} / \mathrm{N}$ were more sensitive to 15 -min exposure to $\mathrm{CO}_{2}$ than $4 \mathrm{R} / \mathrm{N}$ and $3 \mathrm{R} / \mathrm{N \# 1}$, respectively. 
a progressive increase in $\mathrm{Cx} 32$ sensitivity to $\mathrm{CO}_{2}$ (Figure 7). Interestingly, the $5 \mathrm{R}$ residues were not all equally effective in inhibiting the $\mathrm{Cx} 32$ sensitivity to $\mathrm{CO}_{2}$. R215 has greater inhibitory power than R219-220, whereas R223-224 seems to partly counteract the inhibitory activity of both R215 and $\mathrm{R} 219-220$. This is suggested by the fact that $2 \mathrm{R} / \mathrm{N}$ and $1 \mathrm{R} / \mathrm{N}$ were more sensitive to 15 min exposure to $\mathrm{CO}_{2}$ than $4 \mathrm{R} / \mathrm{N}$ and $3 \mathrm{R} /$ $\mathrm{N} \# 1$, respectively (Figure 7).

A possible interpretation of these data is that the gating mechanism involves electrostatic interactions among intracellular domains of $\mathrm{Cx} 32 . \mathrm{IL}_{2}$ and $\mathrm{C}_{1}$ are positively charged domains in all connexins, whereas $\mathrm{IL}_{1}$ is the only cytoplasmic domain that is rich in negative charges. Although $\mathrm{IL}_{1}$ contains positive charges as well, being the most heavily charged domain of connexins, in $\alpha$ helical conformation it would have positive and negative charges partitioned on opposite sides of the helix (Figure 8); indeed, $\mathrm{IL}_{1}, \mathrm{IL}_{2}$ and $\mathrm{C}_{1}$ of $\mathrm{Cx} 32$ are likely to be $\alpha$-helical and IL may have a helix-loop-helix structure, in view of the presence of $\mathrm{G}$ (residues 110 and 112) and $P$ (residue 114) residues at its midregion.

As a working model, we are considering the possibility that in $\mathrm{Cx} 32$ under normal coupling conditions the negative charges of $\mathrm{IL}_{1}$ are masked or somehow unavailable for electrostatic interaction with other domains. With $\mathrm{CO}_{2}$, conformational changes, brought about by changes in the connexin phosphorylation state, protonation of $\mathrm{H}$ residues, $\mathrm{CaM}$ binding, a combination of the above, or other as yet unknown factors, may expose them, allowing $\mathrm{IL}_{2}$ and $\mathrm{C}_{1}$ to competitively interact with $\mathrm{IL}_{1}$. $\mathrm{IL}_{1}-\mathrm{IL}_{2}$ interaction would result in a closed channel state, whereas $\mathrm{IL}_{1^{-}}$ $\mathrm{C}_{1}$ interaction would maintain the channel in an open state (Figure 8). Based on this hypothesis, uncoupling efficiency would de-

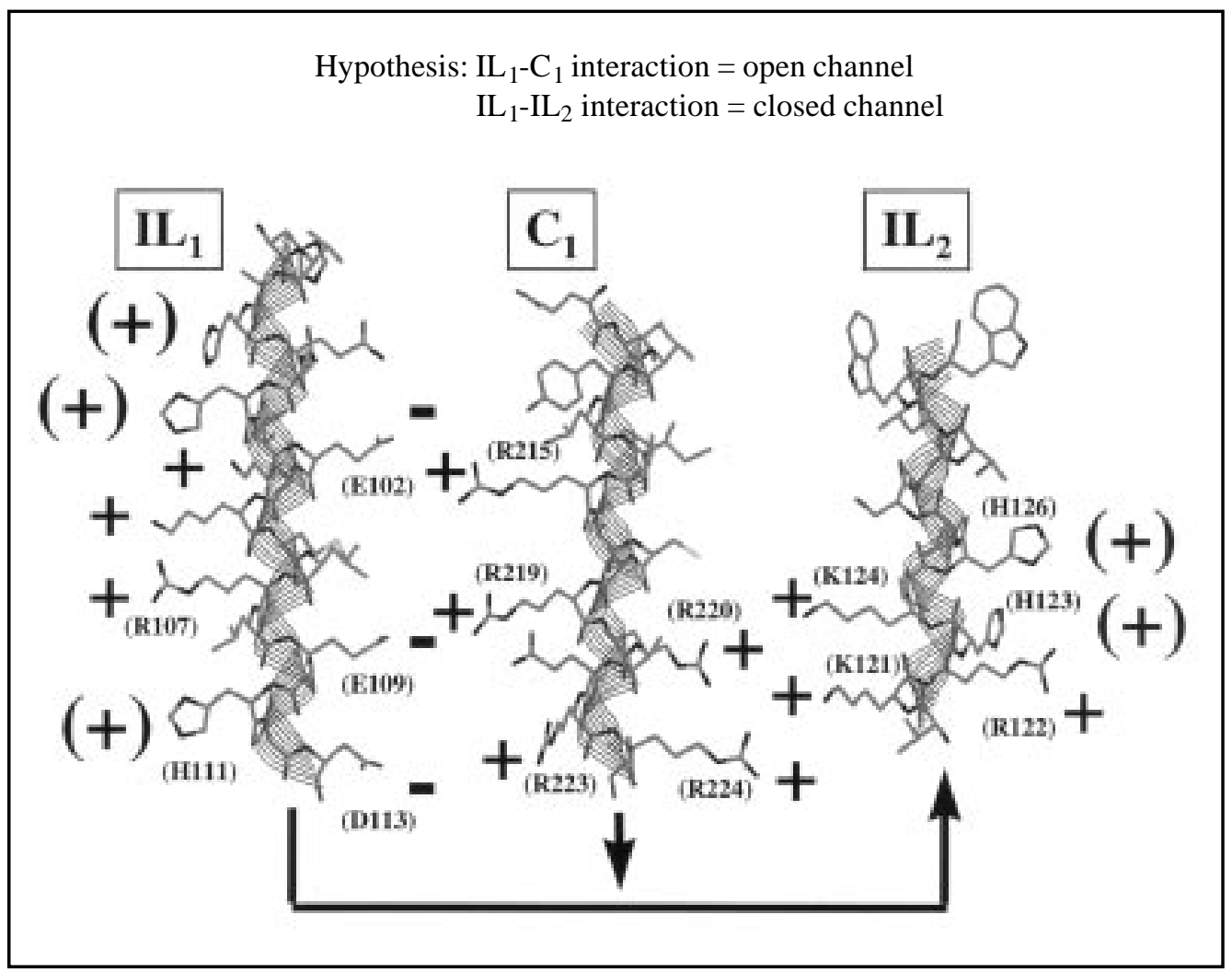

Figure 8 - Model of potential electrostatic interactions among three cytoplasmic domains $\left(I L_{1}\right.$, $\mathrm{IL}_{2}$ and $\mathrm{C}_{1}$ ) of $\mathrm{C} \times 32$, displayed in alpha-helical conformation. In view of the fact that 1) $\mathrm{IL}_{2}$ and $\mathrm{C}_{1}$ are positively charged, 2 ) the inhibitory action of $\mathrm{C}_{1}$ depends on its positive charges, and 3 ) the only cytoplasmic domain with negative charges is $\mathrm{IL}_{1}$ (not considering some acidic residues of the C-terminal domain that can be deleted without gating consequences), we propose that open and closed channel states depend on charge interactions among $\mathrm{IL}_{1}, \mathrm{IL}_{2}$ and $\mathrm{C}_{1}$. In coupled conditions the negative charges of $\mathrm{IL}_{1}$ would be unavailable for interaction, whereas with $\mathrm{CO}_{2}$ conformational changes would expose them, enabling $\mathrm{IL}_{2}$ and $\mathrm{C}_{1}$ to competitively interact with $I L_{1} \cdot I L_{1}-I_{2}$ interaction would result in closed channel, whereas $\mathrm{IL}_{1}-\mathrm{C}_{1}$ interaction would maintain the channel open. 
Figure 9 - Gap junction channels can be homotypic (made of two connexons expressing the same connexin) (a) or heterotypic (made of two connexons each expressing a different connexin) (b). Similarly, connexons can be homomeric (made of the same connexin) ( $a$ and b) or heteromeric (composed of different connexins) (c and d). Therefore, cell-cell channels can be homomeric-homotypic (a), homomeric-heterotypic (b), monoheteromeric (one connexon heteromeric and the other homomeric) (c), or biheteromeric (both connexons heteromeric) (d).

pend on differences between $\mathrm{IL}_{2}$ and $\mathrm{C}_{1}$ in binding affinity to $\mathrm{IL}_{1}$. In $\mathrm{Cx} 32$, one would predict $\mathrm{C}_{1}$ to be a strong competitor of $\mathrm{IL}_{2}$, whereas the opposite would be true for connexins more sensitive to $\mathrm{CO}_{2}$, such as $\mathrm{Cx} 38$, $\mathrm{Cx} 50, \mathrm{Cx} 45$, etc. The gradual increase in Cx32 sensitivity to $\mathrm{CO}_{2}$ that follows the progressive removal of positive charges in $\mathrm{C}_{1}$ would be the consequence of a gradual decrease in the capacity of $\mathrm{C}_{1}$ and $\mathrm{IL}_{1}$ to interact with each other. The increased $\mathrm{CO}_{2}$ sensitivity of the $\mathrm{Cx} 32 / 38 \mathrm{I}_{2}$ chimera, compared to wild-type $\mathrm{Cx} 32$, would indicate that $\mathrm{IL}_{2}$ of $\mathrm{Cx} 38$ has greater affinity for $\mathrm{IL}_{1}$ of $\mathrm{C} x 32$ than $\mathrm{IL}_{2}$ of $\mathrm{Cx} 32$. Therefore, $\mathrm{IL}_{2}$ of Cx38 would compete more efficiently against the inhibitory domain $\left(\mathrm{C}_{1}\right)$ for binding to $\mathrm{IL}_{1}$. Although one should be well aware that based on the very limited amount of data this and any other potential model should not be valued more than working hypotheses, we feel that the potential participation of electrostatic interactions among connexin domains in the gating mechanism is worth careful study.

A puzzling question is the apparent contradiction between our data on Cx32 and those of Delmar's group $(40,70,71)$ on $\mathrm{Cx} 43$ regarding the relevance of $\mathrm{CT}$ in $\mathrm{CO}_{2}$ gating. Whereas we found most of the $\mathrm{CT}$ of $\mathrm{Cx} 32$ to be irrelevant and its initial regions $\left(\mathrm{C}_{1}\right)$ to act as a gating inhibitor, Delmar's group found

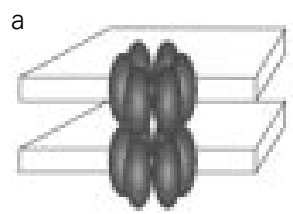

Homomeric-homotypic

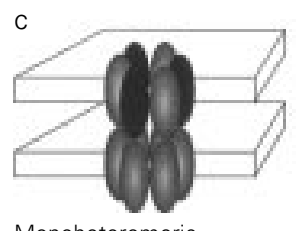

Monoheteromeric

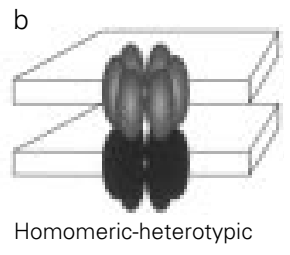

d

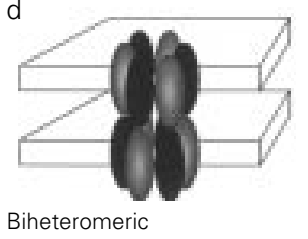

middle (residues 261-300) and end (residues 374-382) regions of the CT of $\mathrm{Cx} 43$ to be gating mediators (or activators); indeed, they have named the end of CT "the gating particle" of the ball-and-chain model (71). Of course, it is quite possible that connexins are gated by different molecular mechanisms. On the other hand, we think that there might be a common denominator for $\mathrm{Cx} 32$ and $\mathrm{Cx} 43$ data. A possibility is that in $\mathrm{Cx} 43$ the negatively charged region of the "gating particle" interacts with $C_{1}$ (a basic-amphiphilic domain, as in Cx32). By doing so, the "gating particle" would eliminate the inhibitory function of $\mathrm{C}_{1}$, as it would prevent it from interacting with $\mathrm{IL}_{1}$; its deletion would reduce $\mathrm{CO}_{2}$ sensitivity because $\mathrm{C}_{1}$ would then be free to bind to $\mathrm{IL}_{1}$ and to act as inhibitor domain by competing against $\mathrm{IL}_{2}$. Indeed, acidic residues of the "gating particle" were found to be crucial for its function (71). The proline-glycine-rich mid-region of CT may provide the hinge that enables the "gating particle" to bend backward and bind to $C_{1}$. Based on this interpretation, the reason why coexpressing Cx32 with the "gating particle" of $\mathrm{Cx} 43$ increases the $\mathrm{CO}_{2}$ sensitivity of Cx32 $(70,71)$ would be that the "gating particle" of $\mathrm{Cx} 43$ interacts electrostatically with $\mathrm{C}_{1}$ of $\mathrm{Cx} 32$ and blocks its inhibitory function. Note that in $\mathrm{Cx} 32$ the end of the CT chain does not contain sequences even remotely similar to that of the "gating particle".

\section{Does chemical gating require connexin cooperativity?}

Coupling between cells expressing different connexins has been demonstrated in many systems (1), indicating that a cell-cell channel can be homotypic (made of two connexons expressing the same connexin, Figure 9a) or heterotypic (made of two connexons each expressing a different connexin, Figure 9b) (1). In turn, connexons can be homomeric (made of the same connexin, 
Figure 9a and b) or heteromeric (composed of different connexins, Figure 9c and d) (79). Therefore, cell-cell channels can be homomeric-homotypic (Figure 9a), homomericheterotypic (Figure 9b), monoheteromeric (one connexon heteromeric and the other homomeric, Figure 9c), biheteromeric (both connexons heteromeric, Figure 9d), etc.

In view of this complexity, we have recently begun addressing questions on $\mathrm{CO}_{2}$ gating in heteromeric connexons and heterotypic channels. We think that heteromeric connexons are an excellent tool for learning whether $\mathrm{CO}_{2}$ gating requires cooperativity among the connexins of a connexon. Similarly, heterotypic channels can help determining whether the two connexons of a cellcell channel influence each other's gating behavior. Our preliminary data indicate that connexin cooperativity within a connexon (hemichannel) may be necessary (80). If this were true, one would expect physiologically occurring heteromeric hemichannels to gate poorly, resulting in important functional consequences for tissue behavior.

We have tested oocyte pairs in which one oocyte expresses a 50/50 mixture of wildtype $\mathrm{Cx} 32$ and 5R/N mutant (mixed oocyte) and the other either wild-type $\mathrm{Cx} 32$ (32 oocyte) or $5 \mathrm{R} / \mathrm{N}$ mutant ( $R / \mathrm{N}$ oocyte), creating mixed-32 and mixed- $R / N$ pairs (both with monoheteromeric channels, Figure 9c). Interestingly, these pairs were much less sensitive than $32-32$ and $R / N-R / N$ pairs, respectively (Figure 10). Since the $5 \mathrm{R} / \mathrm{N}$ mutant is much more sensitive to $\mathrm{CO}_{2}$ than the wildtype Cx32 (Figure 7), if connexins were gating independently from each other one would have expected the mixed-32 to be more sensitive than 32-32 and the mixed-R/ $N$ to be only slightly less sensitive than $R / N$ $R / N$ pairs. The presence of one or more $5 \mathrm{R} /$ $\mathrm{N}$ in most hemichannels should have increased the gating sensitivity of the heteromeric hemichannels.

Whereas connexin cooperativity within a connexon may be needed for efficient gat- ing, cooperativity between two connexons forming a cell-cell channel may not be necessary. In our preliminary data, $32-R / N$ pairs (homomeric heterotypic, Figure $9 \mathrm{~b}$ ) were less sensitive than $R / N-R / N$ pairs and more sensitive than 32-32 pairs (Figure 10) to a level predicted for independent hemichannel gating.

\section{Conclusion}

The chemical gating of gap junction channels appears to be a complex phenomenon that involves more than one connexin domain. Both an increase in cytosolic calcium concentration and a decrease in $\mathrm{pH}_{\mathrm{i}}$ appear to initiate the cell-cell uncoupling process, but based on our data the effect of low $\mathrm{pH}_{\mathrm{i}}$ on gap junction channels appears to be primarily mediated by an increase in cytosolic free calcium concentration. The chain of events that link the increase in calcium and/or hydrogen ion concentration to the channel gating mechanism is unclear, although indirect evidence suggests a role of calmodulin in the uncoupling process. At the molecular level, two connexin domains have been considered important: the inner (cytoplasmic) loop and the carboxy-terminus chain. However, different functions have been attributed to the latter in $\mathrm{Cx} 32$ and in $\mathrm{Cx} 43$.

The absence of high resolution structural

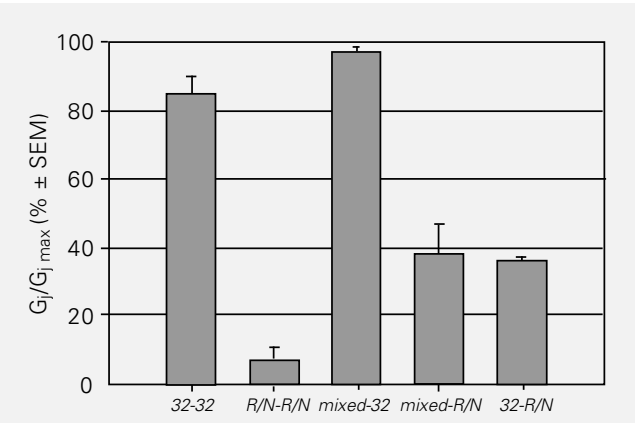

Figure 10 - Sensitivity to $\mathrm{CO}_{2}$ presented as normalized junctional conductance $\left(\mathrm{G}_{\mathrm{j}} / \mathrm{G}_{\mathrm{j}}\right.$ maxi $100 \%=$ control, pretreatment value) in oocyte pairs expressing heteromeric or heterotypic channels. Pairs in which one oocyte expressed a 50/50 mixture of Cx32 and 5R/N mutant (mixed) and the other either $\mathrm{C} \times 32$ (32) or $5 \mathrm{R} / \mathrm{N}(R / N)$ were less sensitive to $\mathrm{CO}_{2}$ than $32-32$ and $R / N-R / N$ pairs, respectively. Their sensitivity is consistent with the idea that in heteromeric hemichannels (mixed) gating is impaired and suggests that gating may require connexin cooperativity. In contrast, the sensitivity of heterotypic channels $(32-R / N)$ was close to that theoretically predicted, indicating that the two hemichannels of a cell-cell channel are likely to gate independently from each other. 
information is the major handicap for understanding channel gating mechanisms at the molecular level. Nonetheless, important information on the gating process will continue to accumulate through connexin chimeras and mutants. A thorough study of relevant connexin domains based on molecular genetics and biophysics, coupled to careful comparisons of connexin sequences and gating behaviors, should provide a good un- derstanding of the molecular mechanism of channel gating even in the absence of a detailed portrait of the three-dimensional architecture of connexin.

\section{Acknowledgment}

The authors are grateful to Ms. Lillian M. Peracchia for excellent technical help.

\section{References}

1. Bruzzone R, White TW \& Paul DL (1996). Connections with connexins: The molecular basis of direct intercellular signaling. European Journal of Biochemistry, 238: 1-27.

2. Garfield RE \& Hertzberg EL (1990). Cell-to-cell coupling in the myometrium: Emil Bozler's prediction. Progress in Clinical and Biological Research, 327: 673-682.

3. Bergoffen J, Scherer SS, Wang S, Scott MO, Bone LJ, Paul DL, Chen K, Lensch MW, Chance PF \& Fischbeck KH (1993). Connexin mutations in X-linked Charcot-Marie-Tooth disease. Science, 262: 2039-2042.

4. Ionasescu V, Searby C \& Ionasescu R (1994). Point mutations of the connexin32 (GJB1) gene in X-linked dominant Charcot-Marie-Tooth neuropathy. Human Molecular Genetics, 3: 355-358.

5. Fairweather N, Bell C, Cochrane S, Chelly J, Wang S, Mostacciuolo ML, Monaco AP \& Haites NE (1994). Mutations in the connexin 32 gene in X-linked dominant Charcot-Marie-Tooth disease (CMTX1). Human Molecular Genetics, 3: 29-34.

6. Spray DC (1994). CMTX1: A gap junction genetic disease. Lancet, 343: 1111-1112.

7. Britz-Cunningham SH, Shah MM, Zuppan CW \& Fletcher WH (1995). Mutations of the connexin43 gap-junction gene in patients with heart malformations and defects of laterality. New England Journal of Medicine, 332: 1323-1329.

8. Perez-Velazquez JL, Valiante TA \& Carlen PL (1994). Modulation of gap junctional mechanisms during calcium-free induced field burst activity: A possible role for electrotonic coupling in epileptogenesis. Journal of Neuroscience, 14: 4308-4317.

9. Nedergaard M, Cooper AJL \& Goldman SA (1995). Gap junctions are required for the propagation of spreading depression. Journal of Neurobiology, 28: 433-444.
10. Campos de Carvalho AC, Tanowitz HB, Wittner M, Dermietzel R, Roy C, Hertzberg EL \& Spray DC (1992). Gap junction distribution is altered between cardiac myocytes infected with Trypanosoma cruzi. Circulation Research, 70: 733-742.

11. Peracchia C (1980). Structural correlates of gap junction permeation. International Review of Cytology, 66: 81-146.

12. Peracchia C, Lazrak A \& Peracchia LL (1994). Molecular models of channel interaction and gating in gap junctions. In: Peracchia C (Editor), Handbook of Membrane Channels. Molecular and Cellular Physiology. Academic Press, San Diego, 361-377.

13. Zimmer DB, Green CR, Evans WH \& Gilula NB (1987). Topological analysis of the major protein in isolated intact rat liver gap junctions and gap junction-derived single membrane structures. Journal of Biological Chemistry, 262: 7751-7763.

14. Hertzberg EL, Disher RM, Tiller AA, Zhou $Y$ \& Cook R (1988). Topology of the Mr 27,000 liver gap junction protein. Journal of Biological Chemistry, 263: 1910519111.

15. Milks LC, Kumar NM, Houghten R, Unwin N \& Gilula NB (1988). Topology of the 32-kd liver gap junction protein determined by site-directed antibody localizations. EMBO Journal, 7: 2967-2975.

16. Goodenough DA, Paul DL \& Jesaitis L (1988). Topological distribution of two connexin32 antigenic sites in intact and split rodent hepatocyte gap junctions. Journal of Cell Biology, 107: 1817-1824.

17. Yancey SB, John SA, Lal R, Austin BJ \& Revel J-P (1989). The 43-kD polypeptide of heart gap junctions: Immunolocalization, topology, and functional domains. Journal of Cell Biology, 108: 2241-2254.
18. Laird DW \& Revel J-P (1990). Biochemical and immunochemical analysis of the arrangement of connexin43 in rat heart gap junction membranes. Journal of Cell Science, 97: 109-117.

19. Meyer RA, Laird DW, Revel JP \& Johnson RG (1992). Inhibition of gap junction and adherent junction assembly by connexin and A-CAM antibodies. Journal of Cell Biology, 119: 179-189.

20. Yeager M \& Gilula NB (1992). Membrane topology and quaternary structure of cardiac gap junction ion channels. Journal of Molecular Biology, 223: 929-948.

21. Zhang J-T \& Nicholson BJ (1994). The topological structure of connexin 26 and its distribution compared to connexin 32 in hepatic gap junctions. Journal of Membrane Biology, 139: 15-29.

22. Leube RE (1995). The topogenic fate of the polytopic transmembrane proteins, synaptophysin and connexin, is determined by their membrane-spanning domains. Journal of Cell Science, 108: 883-894.

23. Peracchia C (1990). Increase in gap junction resistance with acidification in crayfish septate axons is closely related to changes in intracellular calcium but not hydrogen ion concentration. Journal of Membrane Biology, 113: 75-92.

24. Lazrak A \& Peracchia C (1993). Gap junction gating sensitivity to physiological internal calcium regardless of $\mathrm{pH}$ in Novikoff hepatoma cells. Biophysical Journal, 65: 2002-2012.

25. Lazrak A, Peres A, Giovannardi S \& Peracchia C (1994). Ca-mediated and independent effects of arachidonic acid on gap junctions and Ca-independent effects of oleic acid and halothane. Biophysical Journal, 67: 1052-1059. 
26. Mears D, Sheppard Jr NF, Atwater I \& Rojas E (1995). Magnitude and modulation of pancreatic ß-cell gap junction electrical conductance in situ. Journal of Membrane Biology, 146: 163-176.

27. Crow JM, Atkinson MM \& Johnson RG (1994). Micromolar levels of intracellular calcium reduce gap junctional permeability in lens cultures. Investigative Ophthalmology and Visual Science, 35: 33323341.

28. Peracchia C, Wang XG, Li LQ \& Peracchia LL (1996). Inhibition of calmodulin expression prevents low-pH-induced gap junction uncoupling in Xenopus oocytes. Pflügers Archiv, 431: 379-387.

29. Loewenstein WR (1966). Permeability of membrane junctions. Annals of the New York Academy of Sciences, 137: 441-472.

30. Délèze J (1965). Calcium ions and the healing-over in heart fibers. In: Taccardi T \& Marchetti C (Editors), Electrophysiology of the Heart. Pergamon Press, Elmsford, New York, 147-148.

31. Délèze J \& Loewenstein WR (1976). Permeability of a cell junction during intracellular injection of divalent cations. Journal of Membrane Biology, 28: 71-86.

32. Rose B \& Loewenstein WR (1976). Permeability of a cell junction and the local cytoplasmic free ionized calcium concentration: a study with aequorin. Journal of Membrane Biology, 28: 87-119.

33. De Mello WC (1975). Effect of intracellular injection of calcium and strontium on cell communication in heart. Journal of Physiology, 250: 231-245.

34. Turin L \& Warner AE (1977). Carbon dioxide reversibly abolishes ionic communication between cells of early amphibian embryo. Nature, 270: 56-57.

35. Turin $L \&$ Warner AE (1980). Intracellular $\mathrm{pH}$ in early Xenopus embryos: its effect on current flow between blastomeres. Journal of Physiology, 300: 489-504.

36. Spray DC, Harris AL \& Bennett MV (1981). Gap junctional conductance is a simple and sensitive function of intracellular $\mathrm{pH}$. Science, 211: 712-715.

37. Ramón F \& Rivera A (1987). Gap junction channel modulation: a physiological viewpoint. Progress in Biophysics and Molecular Biology, 48: 127-153.

38. Peracchia C (1987). Permeability and regulation of gap junction channels in cells and in artificial lipid bilayers. In: De Mello WC (Editor), Cell-to-Cell Communication. Plenum Press, New York, 65-102.

39. Pressler ML (1989). Intracellular $\mathrm{pH}$ and cell-to-cell transmission in sheep Purkinje fibers. Biophysical Journal, 55: 53-65.
40. Liu S, Taffet S, Stoner L, Delmar M, Vallano ML \& Jalife J (1993). A structural basis for the unequal sensitivity of the major cardiac and liver gap junctions to intracellular acidification: The carboxyl tail length. Biophysical Journal, 64: 14221433.

41. Peracchia C (1990). Effects of caffeine and ryanodine on low $\mathrm{pH}_{\mathrm{i}}$-induced changes in gap junction conductance and calcium concentration in crayfish septate axons. Journal of Membrane Biology, 117: 79-89.

42. Oliveira-Castro GM \& Loewenstein WR (1971). Junctional membrane permeability: effects of divalent cations. Journal of Membrane Biology, 5: 51-77.

43. Spray DC, Stern JH, Harris AL \& Bennett MV (1982). Gap junctional conductance: comparison of sensitivities to $\mathrm{H}$ and $\mathrm{Ca}$ ions. Proceedings of the National Academy of Sciences, USA, 79: 441-445.

44. Weingart $R$ (1977). Action of ouabain on intercellular coupling and conduction-velocity in mammalian ventricular muscle. Journal of Physiology, 264: 341-365.

45. Dahl G \& Isenberg G (1980). Decoupling of heart muscle cells: correlation with increased cytoplasmic calcium activity and with changes of nexus ultrastructure. Journal of Membrane Biology, 53: 63-75.

46. Neyton J \& Trautmann A (1986). Physiological modulation of gap junction permeability. Journal of Experimental Biology, 124: 93-114.

47. Maurer $P$ \& Weingart $R$ (1987). Cell pairs isolated from adult guinea pig and rat hearts: effects of $\left[\mathrm{Ca}^{2+}\right]_{i}$ on nexal membrane resistance. Pflügers Archiv, 409: 394-402.

48. Noma A \& Tsuboi N (1987). Dependence of junctional conductance on proton, calcium and magnesium ions in cardiac paired cells of guinea-pig. Journal of Physiology, 382: 193-211.

49. Veenstra RD \& DeHaan RL (1988). Cardiac gap junction channel activity in embryonic chick ventricle cells. American Journal of Physiology, 254: H170-H180.

50. Christ GJ, Moreno AP, Melman A \& Spray DC (1992). Gap junction-mediated intercellular diffusion of $\mathrm{Ca}^{2+}$ in cultured human corporal smooth muscle cells. American Journal of Physiology, 263: C373-C383.

51. Brehm P, Lechleiter J, Smith S \& Dunlap $K$ (1989). Intercellular signaling as visualized by endogenous calcium-dependent bioluminescence. Neuron, 3: 191-198.
52. Dunlap K, Takeda K \& Brehm P (1987). Activation of a calcium-dependent photoprotein by chemical signaling through gap junctions. Nature, 325: 60-62.

53. Johnston MF \& Ramón F (1981). Electrotonic coupling in internally perfused crayfish segmented axons. Journal of Physiology, 317: 509-518.

54. Peracchia C, Bernardini G \& Peracchia LL (1981). A calmodulin inhibitor prevents gap junction crystallization and electrical uncoupling. Journal of Cell Biology, 91: 124 (Abstract).

55. Peracchia C, Bernardini G \& Peracchia LL (1983). Is calmodulin involved in the regulation of gap junction permeability? Pflügers Archiv, 399: 152-154.

56. Hertzberg EL \& Gilula NB (1981). Liver gap junctions and lens fiber junctions: comparative analysis and calmodulin interaction. Cold Spring Harbor Symposia on Quantitative Biology, 46: 639-645.

57. Peracchia C (1984). Communicating junctions and calmodulin: inhibition of electrical uncoupling in Xenopus embryo by calmidazolium. Journal of Membrane Biology, 81: 49-58.

58. Peracchia C (1987). Calmodulin-like proteins and communicating junctions. Electrical uncoupling of crayfish septate axons is inhibited by the calmodulin inhibitor W7 and is not affected by cyclic nucleotides. Pflügers Archiv, 408: 379-385.

59. Wojtczak JA (1985). Electrical uncoupling induced by general anesthetics: a calcium-independent process? In: Bennett MVL \& Spray DC (Editors), Gap Junctions. Cold Spring Harbor Laboratory, Cold Spring Harbor, New York, 167-175.

60. Tuganowski W, Korczynska I, Wasik K \& Piatek G (1989). Effects of calmidazolium and dibutyryl cyclic AMP on the longitudinal internal resistance in sinus node strips. Pflügers Archiv, 414: 351-353.

61. Gandolfi SA, Duncan G, Tomlinson J \& Maraini G (1990). Mammalian lens inter-fiber resistance is modulated by calcium and calmodulin. Current Eye Research, 9: 533-541.

62. Arellano RO, Ramón $F$, Rivera $A$ \& Zampighi GA (1988). Calmodulin acts as an intermediary for the effects of calcium on gap junctions from crayfish lateral axons. Journal of Membrane Biology, 101: 119-131.

63. Van Eldik LJ, Hertzberg EL, Berdan RC \& Gilula NB (1985). Interaction of calmodulin and other calcium-modulated proteins with mammalian and arthropod junctional membrane proteins. Biochemical and Biophysical Research Communications, 126: 825-832. 
64. Fujimoto K, Araki N, Ogawa K-S, Kondo S, Kitaoka T \& Ogawa K (1989). Ultracytochemistry of calmodulin binding sites in myocardial cells by staining of frozen thin sections with colloidal gold-labeled calmodulin. Journal of Histochemistry and Cytochemistry, 37: 249-256.

65. Toyama J, Sugiura H, Kamiya K, Kodama I, Terasawa M \& Hidaka H (1994).

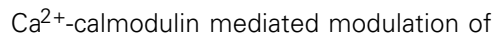
the electrical coupling of ventricular myocytes isolated from guinea pig heart. Journal of Molecular and Cellular Cardiology, 26: 1007-1015.

66. Sáez JC, Nairn AC, Czernik AJ, Spray DC, Hertzberg EL, Greengard P \& Bennett MVL (1990). Phosphorylation of connexin 32, a hepatocyte gap-junction protein, by cAMP-dependent protein kinase, protein kinase $\mathrm{C}$ and $\mathrm{Ca}^{2+}$ /calmodulin-dependent protein kinase II. European Journal of Biochemistry, 192: 263-273.

67. Musil LS, Cunningham BA, Edelman GM \& Goodenough DA (1990). Differential phosphorylation of the gap junction protein connexin43 in junctional communication-competent and -deficient cell lines. Journal of Cell Biology, 111: 2077-2088.

68. Armstrong CM (1966). Time course of TEA $^{+}$-induced anomalous rectification in squid giant axons. Journal of General Physiology, 50: 491-503.

69. Zagotta WN, Hoshi T \& Aldrich RW (1990). Restoration of inactivation in mutants of
Shaker potassium channels by a peptide derived from ShB. Science, 250: 568-571.

70. Morley GE, Taffet SM \& Delmar M (1996). Intramolecular interactions mediate $\mathrm{pH}$ regulation of connexin43 channels. Biophysical Journal, 70: 1294-1302.

71. Ek-Vitorin JF, Calero G, Morley GE, Coombs W, Taffet SM \& Delmar M (1996). pH regulation of connexin43: molecular analysis of the gating particle. Biophysical Journal, 71: 1273-1284.

72. Werner $R$, Levine $E$, Rabadan-Diehl C \& Dahl G (1991). Gating properties of connexin32 cell-cell channels and their mutants expressed in Xenopus oocytes. Proceedings of the Royal Society of London, Series B: Biological Sciences, 243 5-11.

73. Wang XG \& Peracchia C (1996). Molecular domains relevant for chemical gating in gap junction channels made of connexin32. Molecular Biology of the Cell, 7: 462 (Abstract).

74. Wang XG, Li LQ, Peracchia LL \& Peracchia C (1996). Chimeric evidence for a role of the connexin cytoplasmic loop in gap junction channel gating. Pflügers Archiv, 431: 844-852.

75. Wang XG \& Peracchia C (1996). Connexin32/38 chimeras suggest a role for the second half of the inner loop in gap junction gating by low $\mathrm{pH}$. American Journal of Physiology, 271: C1743-C1749.
76. Spray DC \& Burt JM (1990). Structure-activity relations of the cardiac gap junction channel. American Journal of Physiology, 258: C195-C205.

77. Ek JF, Delmar M, Perzova R \& Taffet SM (1994). Role of histidine 95 on pH gating of the cardiac gap junction protein connexin43. Circulation Research, 74: 1058-1064

78. Hermans MMP, Kortekaas $\mathrm{P}$, Jongsma $\mathrm{HJ}$ \& Rook MB (1996). The role of histidine residues on $\mathrm{pH}$ sensitivity of the gap junction protein connexin 43. Molecular Biology of the Cell, 7: 91 (Abstract).

79. Brink PR, Cronin K, Petersen-Grine E, Beyer EC, Veenstra RD, Varadaraj K \& Christ GJ (1996). Evidence for heteromeric forms in cell systems expressing both $\mathrm{C} \times 37$ and $\mathrm{C} \times 43$ : comparison with homotypic $\mathrm{C} \times 37$ and $\mathrm{C} \times 43$. Proceedings of the Keystone Symposium on Molecular Approaches to the Function of Intercellular Junctions. Lake Tahoe, CA, March 1-7, 17 (Abstract).

80. Wang XG \& Peracchia C (1997). Is connexin cooperativity necessary for chemical gating of gap junction channels? Biophysical Journal, 72: A 292. 